\title{
Antibiotic resistance in tap water during the summer season - preliminary research
}

\author{
Agata Siedlecka ${ }^{1, *}$, and Katarzyna Piekarska ${ }^{1}$ \\ ${ }^{1}$ Wrocław University of Science and Technology, Faculty of Environmental Engineering, Department \\ of Sanitary Biology and Ecotechnology, Wyb. Wyspiańskiego 27, 50-370 Wrocław, Poland
}

\begin{abstract}
Antibiotic resistance of bacteria is regarded as a global health risk and should be monitored in all environments, including tap water distribution systems. In this study, tap water samples were collected from two water treatment plants and selected points-of-use from the water distribution network. The abundances of antibiotic resistant bacteria were determined via culture-dependent method and the presence of selected antibiotic resistance genes was detected via PCR. The influence of the distance of points-of-use from water treatment plants on bacterial loads and antibiotic resistance phenomenon was evaluated. The paper presents preliminary results of a large-scale study concerning spatial and seasonal variation in antibiotic resistance of bacteria dwelling in the tap water system in Wrocław.
\end{abstract}

\section{Introduction}

Antibiotic resistance of bacteria became a serious threat to human health decades ago [1], decreasing the potential of antimicrobial therapies. To date, however, antimicrobial agents remain the most popular tool in fight with microbial infections, as the alternative methods of treatment are scarcely developing [2]. Thus, the monitoring of antibiotic resistant bacteria (ARB) and antibiotic resistance genes (ARGs) in the environment is still needed, as it may help to tracking the resistance patterns and contribute to better understanding of resistance phenomenon, as well as to indicate possible ways to deal with this worldwide problem $[3,4]$.

In recent years, the occurrence of ARB and ARGs in drinking water were investigated more and more frequently [5-7], as it was revealed that resistance to antibiotics is often correlated with resistance to disinfectants $[8,9]$ (however, it is worth to note that this hypothesis is still controversial, as it was stated by Lin et al. [10]) and metals [11], therefore making water treatment plants (WTPs) and tap water distribution systems a niche for ARB dwelling and proliferation.

The investigations of antibiotic resistance could be done via culture-dependent and culture-independent methods. As the cultivation of bacteria dwelling in tap water may be challenging due to their specific metabolic requirements, sometimes difficult to achieve in laboratory conditions, both ways (culture-dependent and culture-independent) should be

*Corresponding author: agata.siedlecka@pwr.edu.pl 
implemented in research on ARB, because their usually weak growth may contribute to underestimations of the issue. From the other hand, the selection of ARGs investigated in a study is also a challenge, as antibiotic resistance may be conferred by multiple genes [10]. Hence, the narrowing of tested ARGs group may introduce some biases, alike. Therefore, in recent years, the NGS method became to be implemented in research on antibiotic resistance in tap water [7, 12, 13], allowing the screening for multiple genes in every sample. Nevertheless, high-throughput qPCR profiling of ARGs is also a solution to overcome the hindrance $[10,14]$.

In this study, tap water samples from two independent WTPs and downstream points-of-use taps were investigated in terms of presence of ARB and ARGs. The tap water distribution system in the city is supplied by Na Grobli WTP and Mokry Dwór WTP. In some points on the pipeline network, tap water is supplied alternately by these two WTPs. However, in this study, the selected sampling points represent the consecutive points of area supplied separately by each WTP.

This paper presents the results of culture-dependent methods, i.e. isolation of bacteria resistant to $\beta$-lactams, fluoroquinolones, $3^{\text {rd }}$ generation cephalosporins and tetracyclines, as well as culture-independent methods, i.e. PCR investigation of ARGs and other genes, obtained in tap water samples collected during summer season sampling campaigns. This research, however, would be carried out in the winter season, to achieve the seasonal comparison of antibiotic resistance phenomenon in tap water distribution systems.

\section{Materials and methods}

\subsection{Sample collection}

Tap water samples were collected from two independent WTPs and 3 subsequent points-ofuse supplied by each WTP ( 8 points in total, please see Figure 1). From each sampling point, samples were collected twice: in July and in August 2018. All samples were collected with accordance to Wrocław Municipal Water and Sewerage Company guidelines, i.e. after few minutes of flushing and tap disinfection. To neutralize the activity of disinfectants, $0.1 \mathrm{~g} / \mathrm{L}$ of sodium thiosulfate was added to containers [15]. During each sampling campaign, up to $15 \mathrm{~L}$ of water were collected in sterile containers, transported to laboratory and processed immediately in sterile manners.

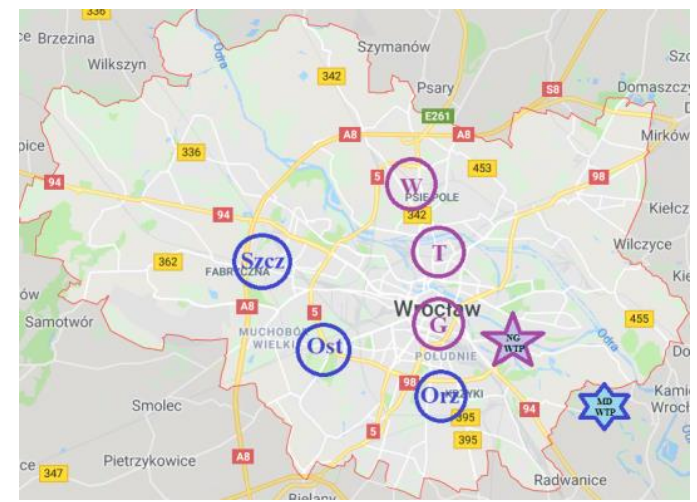

Fig. 1. Sample collection points (NG WTP - Na Grobli WTP; G, T, W - sampling points supplied by Na Grobli WTP; MD WTP - Mokry Dwór WTP; Orz, Ost, Szcz - sampling points supplied by Mokry Dwór WTP). 


\subsection{Culture-dependent methods}

For microbiological research, previously established volumes of tap water samples were filtered through mixed cellulose membranes of $0.2 \mu \mathrm{m}$ pore diameters (Whatman). Afterwards, the membranes were placed on selected agar media and incubated in appropriate conditions, as demonstrated in Table 1. R2A (BTL) agar media were prepared by supplementing the base with selected drug (Sigma-Aldrich) according with Andrews et al. [16] and EUCAST guidelines [17]. Chromogenic agar media are commercially available (BioMaxima).

Table 1. Agar media used in this study, incubation conditions and purposes.

\begin{tabular}{|c|c|c|c|}
\hline $\begin{array}{c}\text { agar } \\
\text { medium }\end{array}$ & $\begin{array}{c}\text { drug and } \\
\text { concentration }\end{array}$ & $\begin{array}{l}\text { incubation } \\
\text { conditions }\end{array}$ & purpose \\
\hline $\mathrm{R} 2 \mathrm{~A}$ & - & \multirow{5}{*}{$\begin{array}{c}22^{\circ} \mathrm{C} \\
7 \mathrm{~d}\end{array}$} & $\begin{array}{l}\text { overall psychrophilic bacteria dwelling in tap } \\
\text { water }\end{array}$ \\
\hline $\mathrm{R} 2 \mathrm{~A}+\beta$ & amoxicillin $[8 \mathrm{mg} / \mathrm{L}]$ & & $\%$ of bacteria resistant to $\beta$-lactams \\
\hline $\mathrm{R} 2 \mathrm{~A}+\mathrm{FQ}$ & $\begin{array}{c}\text { ciprofloxacin [2 } \\
\mathrm{mg} / \mathrm{L}]\end{array}$ & & $\%$ of bacteria resistant to fluoroquinolones \\
\hline $\begin{array}{c}\mathrm{R} 2 \mathrm{~A}+ \\
\mathrm{C} 3 \mathrm{G}\end{array}$ & $\begin{array}{c}\text { ceftazidime }[8 \\
\mathrm{mg} / \mathrm{L}]\end{array}$ & & $\begin{array}{c}\% \text { of bacteria resistant to 3. generation } \\
\text { cephalosporins }\end{array}$ \\
\hline $\mathrm{R} 2 \mathrm{~A}+\mathrm{T}$ & $\begin{array}{l}\text { tetracycline [16 } \\
\mathrm{mg} / \mathrm{L}]\end{array}$ & & $\%$ of bacteria resistant to tetracyclines \\
\hline ESBL & \multirow{4}{*}{$\begin{array}{l}\text { chromogenic agar } \\
\text { media CHROMagar } \\
\text { (BioMaxima) }\end{array}$} & \multirow{4}{*}{$\begin{array}{l}37^{\circ} \mathrm{C} \\
24 \mathrm{~h}\end{array}$} & $\begin{array}{c}\% \text { of bacteria producing } \\
\text { Extended Spectrum Beta-Lactamase }\end{array}$ \\
\hline KPC & & & $\begin{array}{l}\% \text { of bacteria with a reduced susceptibility to } \\
\text { most of the carbapenem agents }\end{array}$ \\
\hline MRSA & & & $\%$ of Methicillin Resistant Staphylococcus aureus \\
\hline VRE & & & $\begin{array}{l}\% \text { of Vancomycin Resistant } E \text {. faecalis and } E \text {. } \\
\text { faecium }\end{array}$ \\
\hline
\end{tabular}

After incubation, the formed colony forming units (cfu) were encountered, and randomly chosen antibiotic resistant strains were purified and subjected for further analyses (data not shown).

\subsection{Culture-independent methods}

For the purpose of DNA extraction, up to $\sim 10 \mathrm{~L}$ of water were filtered through mixed cellulose membranes of $0.2 \mu \mathrm{m}$ pore diameters (Whatman) in sterile manners. Afterwards, the membranes were subjected to extraction procedures with DNeasy PowerWater Kit (QIAGEN), according to manufacturer's instructions. Quantity of obtained DNA samples was verified by NanoPhotometer N60 (Implen). For each sampling point, the DNA extracts from both sampling campaigns were pooled to represent the summer season.

The presence of selected 26 genes were determined by PCR. The reaction mixture consisted of: $12.5 \mu \mathrm{L}$ Start Warm HS-PCR Mix (A\&A Biotechnology), $1 \mu \mathrm{L}$ of each $10 \mu \mathrm{M}$ primer (GenoMed), $2.5 \mu \mathrm{L}$ of DNA and $8 \mu \mathrm{L}$ of water. Each reaction was standardised. The established PCR profile was:

- initial denaturation at $95^{\circ} \mathrm{C}$ for $5 \mathrm{~min}$

- 40 cycles: denaturation at $95^{\circ} \mathrm{C}$ for $15 \mathrm{~s} /$ annealing at $\mathrm{Tm}$ for $30 \mathrm{~s} /$ elongation at $72^{\circ} \mathrm{C}$ for $30 \mathrm{~s}$

- final elongation at $72^{\circ} \mathrm{C}$ for $7 \mathrm{~min}$.

For primers sequences, annealing temperatures, amplicon sizes and references, please see [18]. 
In each reaction, positive and negative controls were implemented. Positive controls were obtained as DNA extracts of bacteria isolated from wastewater samples on antibiotic supplemented media. Negative controls contained all reagents except of DNA.

After PCR amplification, $5 \mu \mathrm{L}$ of each sample were separated by electrophoresis in $2 \%$ or 3\% (depending on amplicon size) agarose gel (Sigma-Aldrich) stained with ethidium bromide $(0.5 \mu \mathrm{g} / \mathrm{mL})$ (Sigma-Aldrich). The products were electrophoresed for $15 \mathrm{~min}$ at $120 \mathrm{~V}$ and for $60 \mathrm{~min}$ at $80 \mathrm{~V}$ in $1 \times \mathrm{TBE}$ buffer and visualized by $\mathrm{UV}$.

\subsection{Additional measurements and analyses}

In each water sample, free and total chlorine was measured at Spectroquant Pharo 300 by Spectroquant Chlorine Cell Test (Merck) in accordance with manufacturer's instructions. Moreover, the results of routine water analyses, i.e. turbidity, conductivity, colour, $\mathrm{pH}$, temperature, chlorine (free and total), chlorites and chlorates, nitrates, aluminium, coliform bacteria, E. coli, C. perfringens (with spores), overall bacteria load (after $72 \mathrm{~h}$ at $22^{\circ} \mathrm{C}$ ), were kindly provided by Wrocław Municipal Water and Sewerage Company.

\section{Results and discussion}

\subsection{Culture-dependent methods and $\mathrm{Cl}_{2}$ measurements}

The percentages of ARB detected in each sample are presented in Table 2. The Table presents the cfu encountered on chromogenic agar media and measured $\mathrm{Cl}_{2}$ concentrations, alike.

Table 2. The occurrence of ARB in collected tap water samples.

\begin{tabular}{|c|c|c|c|c|c|c|c|c|c|c|c|c|}
\hline 葛 & 竞言 &  & $\begin{array}{l}\frac{\pi}{0} \\
\stackrel{0}{0} \\
\tilde{0}\end{array}$ & قै & $\simeq$ & $\stackrel{0}{2}$ & లు & H & $\overrightarrow{00}$ & $\underline{\underline{z}}$ & 芯 & $\frac{1}{y}$ \\
\hline- & - & \multicolumn{2}{|c|}{$\mathrm{mg} / \mathrm{L}$} & $\mathrm{cfu} / \mathrm{mL}$ & \multicolumn{4}{|c|}{$\%$} & \multicolumn{4}{|c|}{$\mathrm{cfu} / 500 \mathrm{~mL}$} \\
\hline 12.07. & $\mathrm{NG}$ & 0.19 & 0.31 & $1.05^{*}$ & $0.19 *$ & $0.00 *$ & $0.19 *$ & $0.00^{*}$ & 1 & & & $*$ \\
\hline 18.07. & $\mathrm{G}$ & 0.07 & 0.13 & $>30$ & 0.00 & 0.00 & 0.05 & 0.00 & & 4 & & $4^{*}$ \\
\hline 10.07 . & $\mathrm{T}$ & 0.10 & 0.14 & 3.00 & $3.87 *$ & 0.47 * & $7.33^{*}$ & 0.00 & & & & \\
\hline 06.07 . & $\mathrm{W}$ & 0.14 & 0.16 & $1.16^{*}$ & $22.07 *$ & $2.41 *$ & $9.66 *$ & $0.34 *$ & & & & \\
\hline 19.07. & MD & 0.27 & 0.40 & 1.21 & 0.99 & 0.00 & $>99.17 *$ & $0.33^{*}$ & & & & \\
\hline 13.07. & Orz & 0.08 & 0.26 & $1.23^{*}$ & $>97.56^{*}$ & $2.44 *$ & $4.23 *$ & $0.00^{*}$ & & & & $1^{*}$ \\
\hline 17.07. & Ost & 0.10 & 0.17 & $1.13^{*}$ & $>85.12 *$ & $1.76^{*}$ & $3.28 *$ & 0.13 & & & & \\
\hline 16.07. & Szcz & 0.07 & 0.16 & 1.48 & $>81.08 *$ & $1.35^{*}$ & 20.27 & $2.43^{*}$ & & & & * \\
\hline 22.08 . & $\mathrm{NG}$ & 0.21 & 0.32 & 0.7 & 0.57 & 0.21 & 0.32 & 0.7 & & 1 & & \\
\hline 09.08 . & $\mathrm{G}$ & 0.12 & 0.19 & 32.0 & $1.53 *$ & 0.12 & 0.19 & 32.0 & & & & \\
\hline 14.08 . & $\mathrm{T}$ & 0.08 & 0.16 & 26.8 & 0.75 & 0.08 & 0.16 & 26.8 & & & & \\
\hline 08.08 . & $\mathrm{W}$ & 0.10 & 0.22 & $57.4^{*}$ & 0.98 & 0.10 & 0.22 & $57.4 *$ & & & & \\
\hline 23.08. & $\mathrm{MD}$ & 0.32 & 0.40 & 0.6 & $0.00^{*}$ & 0.00 & 43.33 & 0.00 & & & & $11^{*}$ \\
\hline 16.08 . & Orz & 0.11 & 0.24 & 10.5 & $6.17 *$ & 0.34 & 1.68 & 0.08 & & & & $4 *$ \\
\hline 28.08 . & Ost & 0.13 & 0.25 & 23.2 & $0.72 *$ & $0.00 *$ & 0.50 & 0.02 & & & & \\
\hline 07.08 . & Szcz & 0.08 & 0.18 & $26.4^{*}$ & 0.33 & 3.58 & 0.85 & $0.71^{*}$ & & & & 10 \\
\hline
\end{tabular}

Legend:

$\mathrm{OB}$ - overall bacteria cultivated on R2A medium

$\beta, \mathrm{FQ}, \mathrm{C} 3 \mathrm{G}, \mathrm{T}-\%$ of $\mathrm{ARB}$ resistant to: $\beta$-lactams, fluoroquinolones, $3^{\text {rd }}$ generation cephalosporins, tetracyclines

ESBL, KPC, MRSA, VRE - cfu encountered on chromogenic agar media after incubation

* - the presence of mould on a plate after incubation

? - the bacteria could not be encountered due to their colony morphology 
There is a clear difference between cfu counting of overall bacteria in July and in August. In July, the even bacterial contamination was observed in each sampling point, except of $\mathrm{G}$, were the cfu counting was clearly higher, what could be explained by accidental contamination. In August, however, the bacterial contamination increased apparently in sampling points located downstream both WTPs. It could be the effect of extremely high temperatures noted in Wrocław during August; however, despite the high air temperature, tap water temperature remained stable in every point-of-use tap in two sampling campaigns (data not shown). The measured concentrations of $\mathrm{Cl}_{2}$ are, in general, in accordance with these provided by Municipal Water and Sewerage Company in Wrocław (some discrepancies are observed in the case of $\mathrm{Cl}_{2}$ free in several points; however, the sampling collection procedures might introduce some biases, as the main purpose was the microbiological research - so the results of $\mathrm{Cl}_{2}$ measurements should be regarded only as indicative). Nevertheless, the slightly higher $\mathrm{Cl}_{2}$ concentrations in samples collected during August do not correspond with bacterial growth reduction.

In July, the increase of resistant microflora downstream WTP in the distribution system might be observed in the case of the area supplied by Na Grobli WTP. However, in the case of the area supplied by Mokry Dwór WTP, this observation is truly only for $\beta$-lactams, fluoroquinolones and tetracyclines, while the treated water is much more contaminated by bacteria resistant to $3^{\text {rd }}$ generation cephalosporins than water collected from downstream points. What arouses curiosity, the same phenomenon might be observed in August.

In August, all points from the area supplied by Na Grobli WTP seem to have even ARB contamination in the cases of $\beta$-lactams, fluoroquinolones and $3^{\text {rd }}$ generation cephalosporins; however, the re-growth of tetracycline resistant microflora downstream the WTP might be observed. Similarly, the percentage of ARB are even in the area supplied by Mokry Dwór WTP, except of $3^{\text {rd }}$ generation cephalosporin resistant bacteria, as it was in July.

These findings are in discordance with the results presented by Grabińska-Łoniewska in Poland, which indicated a stronger relationship between distance of a sampling point from a WTP [19]. Vaz-Moreira et al. suggest that specific conditions prevailing in household taps could influence the community structure and composition of collected microflora [15], what may be an issue also in this study. Nevertheless, this factor should be mitigated by tap water flushing and tap disinfection before samples' collection.

The higher bacterial loads downstream WTPs are observed only in August in this study. A tendency of higher ARB contribution in overall microflora is more apparent in June, however. These may lead to the conclusion, that the overall bacteria and ARB occurrence may be correlated with other physical-chemical parameters, like temperature, nitrates or total organic carbon - but the results of routine water analyses kindly provided by Municipal Water and Sewerage Company do not indicate such relationships. In general, all the measured tap water parameters were with accordance with Polish Ministry of Health Regulations [20]. Nevertheless, the percentages of ARB seem to be very high, especially in several points, as it is presented in the cases of $\beta$-lactam resistant bacteria downstream Mokry Dwór WTP in July, $3^{\text {rd }}$ generation cephalosporins resistant bacteria in Mokry Dwór WTP in July and in August and tetracycline resistant bacteria at the end of pipeline network in the area supplied by Na Grobli WTP in August (typed in bold in Table 2).

It is worth to note that there are rechlorination points in the tap water distribution system in Wrocław. Among the points-of-use taps selected for samples collection in this study, only 'Szcz' point seems to be influenced by rechlorination (concluded on the basis of the location of rechlorination points - data kindly provided by Municipal Water and Sewerage Company). The rechlorination procedure might contribute to the prevention of re-growth of microflora in this sampling point. 


\subsection{Culture-independent methods}

The presence of selected ARGs in DNA samples, representing the summer season, are presented in Table 3.

Table 3. The results of PCR investigations.

\begin{tabular}{|c|c|c|c|c|c|c|c|c|c|}
\hline ARG & NG & G & T & W & MD & Orz & Ost & Szcz & total \\
\hline blaSHV & - & - & - & - & - & - & - & - & \\
\hline blaCTX-M & - & - & - & - & - & - & - & - & \\
\hline blaKPC & - & - & - & - & - & - & - & - & \\
\hline blaNDM & + & - & - & - & - & - & + & - & $\mathbf{2}$ \\
\hline blaOXA & - & - & - & - & $\mathbf{2}$ & - & - & - & $\mathbf{1}$ \\
\hline blaOXA-48 & - & $\mathbf{-}$ & - & - & - & - & - & - & $\mathbf{1}$ \\
\hline mecA & - & - & - & - & - & - & - & - & \\
\hline qnrA & - & - & - & - & - & - & - & - & \\
\hline qnrB & - & - & + & - & - & - & - & - & $\mathbf{1}$ \\
\hline qnrS & + & - & + & - & - & - & - & - & $\mathbf{2}$ \\
\hline oqxB & - & - & - & - & - & - & - & - & \\
\hline tetA & - & - & + & - & - & - & - & $\mathbf{2}$ & $\mathbf{2}$ \\
\hline tetK & - & - & - & - & - & - & - & - & \\
\hline tetL & - & - & - & - & - & - & - & - & \\
\hline tetW & - & - & - & - & - & - & - & - & \\
\hline sulI & - & + & + & + & - & - & - & + & $\mathbf{4}$ \\
\hline sulII & - & + & - & - & - & - & - & - & $\mathbf{1}$ \\
\hline ermA & - & - & - & - & - & - & - & - & \\
\hline ermB & - & - & - & + & - & + & - & - & $\mathbf{2}$ \\
\hline vanA & - & - & - & - & - & - & - & - & \\
\hline mcr-1 & - & - & - & - & - & - & - & - & \\
\hline floR & - & - & - & - & - & - & - & - & \\
\hline qacEAI & - & - & + & $\mathbf{2}$ & - & + & - & - & $\mathbf{3}$ \\
\hline qacH & + & - & + & - & + & + & + & - & $\mathbf{5}$ \\
\hline intII & + & + & + & + & + & + & $+/-$ & + & $\mathbf{8}$ \\
\hline tnpA & - & + & + & + & + & + & + & - & $\mathbf{6}$ \\
\hline total & $\mathbf{4}$ & $\mathbf{5}$ & $\mathbf{8}$ & $\mathbf{5}$ & $\mathbf{4}$ & $\mathbf{5}$ & $\mathbf{4}$ & $\mathbf{3}$ & \\
\hline & & & & & & & & \\
\hline
\end{tabular}

Legend:

+ amplicon band in electrophoresis

- no amplicon band in electrophoresis

+/- very slight amplicon band in electrophoresis

? amplicon band is present, but there is many unspecific products in environmental sample, despie clear band in positive control

Only few genes among the selected group of 26 were detected in tap water samples. Beside ARGs, the genes responsible for HGT (intIl, tnpA) and resistance to disinfectants $(q a c E \Delta 1, q a c H)$ were detected. The presence of amplicons in each DNA sample ensures the lack of PCR inhibitors within. The results do not clearly indicate the proliferation of genetic determinants of resistance in the water distribution system, as the overall number of detected genes are similar in every sample. Moreover, some genes appear only downstream WTPs, two were detected only in WTPs samples (blaNDM, blaOXA), and the others were detected in one or several samples, but without any pattern suggesting their fate in the distribution system. It does not seem like the genes were introduced with treated water, but randomly appeared in several points in the pipeline networks. This might be explained by external contamination of the network (for example as the results of main line renovations etc.) or the presence of biofilm reservoirs of ARB and ARGs within the pipelines [19] - in this case, the accidental detachment of biomass [21] might result in the presence of few ARGs in collected tap water samples. Moreover, tap water samples were not collected from 
chosen point-of-use taps after presumed time of water transfer from the WTP, but this drawback should be mitigated by pooling DNA samples obtained from two sampling campaigns in the summer season.

Among the investigated ARGs, the most frequently detected was sull, responsible for the resistance to sulphonamide. Together with sull gene, genes qacEAl and qacH, responsible for quaternary ammonium compound resistance, are often detected in class 1 integrons [22]. Therefore, the detection of intI1, sull, qacEAl and qacH genes in tap water samples is not surprising, as it was proven, that these genes are commonly present in biofilms formed during water treatment [22].

Nevertheless, the relationship between ARB and ARGs could not be established in this study. Despite the presence of bacteria resistant to $\beta$-lactams, fluoroquinolones, $3^{\text {rd }}$ generation cephalosporins and tetracyclines, the genes providing resistance to these antibiotic classes were not frequently detected. This may indicate the putative presence of other genes conferring resistance to antibiotics, not tested in this study, as there is a large group of genes which may confer resistance to each antibiotic class [10]. Moreover, the genes related to phenotypic resistance to methicillin and vancomycin (mecA and vanA, respectively [23]) where not detected, despite the presence of cfu on MRSA and VRE chromogenic agar media. The same discrepancy should be stated for ESBL and KPC, as even though the growth of bacteria on these chromogenic agar media was proven, no blaSHV, blaCTX-M and blaKPC genes were detected. Nevertheless, the presence of blaNDM, blaOXA and blaOXA-48 might arouse anxiety, as the occurrence of these genes during last years in Poland contributed to serious human health threats [24].

The presumed reason of such low detection of ARGs might be the low DNA concentration. Despite large water volumes used in this study for DNA extraction procedures, the overall bacteria load in treated tap water were low, what may contribute to hampering the detection of genes by standard PCR method. The results presented in this study would be further used in qPCR and NGS analyses of obtained DNA samples for the evaluation of the quantities of detected genes and bacterial biodiversity in tap water samples. Moreover, the antibiotic resistance profiles of chosen resistant strains would be established. Finally, the comprehensive results of ARB and ARGs investigations in summer season would be compared with the results achieved during winter season sampling campaigns (January, February) from the same sampling points.

\section{Conclusions}

The presence of ARB and ARGs in treated waters entering the two water distribution systems and downstream tap water samples was proven in this study. Nevertheless, the evidence of ARB and ARGs proliferation in tap water distribution system could not be established. The distance of sampling points from WTPs seems to not influence the overall bacterial contamination in July, while might be considered a meaning factor in August. From the other hand, despite the even overall bacteria contamination, the percentage of ARB seems to increase with the distance from WTPs in July, but not in August. The genes conferring resistance to disinfectants were detected in almost every sample, while ARGs were detected randomly, without any unequivocal pattern. The additional research is needed to elucidate the achieved results. Moreover, the comparison of the results of summer season and winter season campaigns might contribute to better understanding of the antibiotic resistance of bacteria in the tap water distribution system environment.

The authors would like to thank Municipal Water and Sewerage Company in Wrocław and its employees for their contribution in research, enabling of sample collection and sharing the results of 
tap water analyses. The conference participation was financed from the statutory funds of Faculty of Environmental Engineering, Wroclaw University of Science and Technology from the project 0401/0056/18.

\section{References}

1. J. Davies, D. Davies, Microbiol. Mol. Biol. Rev. 74, 417-33 (2010)

2. A. Kozińska, I. Sitkiewicz, Kosmos 66, 109-124 (2017)

3. F. Baquero, J.-L. Martínez, R. Cantón, Curr. Opin. Biotechnol. 19, 260-265 (2008)

4. J.-L. Martínez, Science 321, 365-367 (2008)

5. S. Khan, C. W. Knapp, T. K. Beattie, Environ. Process 3, 541-552 (2016)

6. I. Vaz-Moreira, O. C. Nunes, C. M. Manaia, Sci. Total Environ. 586, 1141-1149 (2017)

7. L. Ma, B. Li, X.T. Jiang, Y. L. Wang, Y. Xia, A. D. Li, T. Zhang, Microbiome 5, 1-12 (2017)

8. A. Li, S. Cheng, X.-X. Zhang, S. Jia, P. Shi, T. Zhang, Water Res. 47, 111-120 (2012)

9. S. Khan, T. K. Beattie, C. W. Knapp, Chemosphere 152, 132-141 (2016)

10. W. Lin, M. Zhang, S. Zhang, X. Yu, Chemosphere 156, 412-419 (2016)

11. C. Pal, J. Bengtsson-Palme, E. Kristiansson, D. G. J. Larsson, BMC Genomics 16, $1-15$ (2015)

12. V. Gomez-Alvarez, R. P. Revetta, J. W. S. Domingo, Appl. Environ. Microbiol. 78, 6095-6102 (2012)

13. S. Jia, P. Shi, Q. Hu, B. Li, T. Zhang, X.X. Zhang, Environ. Sci. Technol. 49, 12271-12279 (2015)

14. L. Xu, W. Ouyang, Y. Qian, C. Su, J. Su, H. Chen, Environ. Pollut. 213, 119-126 (2016)

15. I. Vaz-Moreira, C. Egas, O. C. Nunes, C.M. Manaia, FEMS Microbiol. Ecol. 83, 361-374 (2013)

16. J. M. Andres, J. Antimicrob. Chemother. 49, 1049-1049 (2002)

17. EUCAST (http://www.eucast.org/)

18. A. Siedlecka, K. Piekarska, Obecność genów warunkujacych oporność na wybrane antybiotyki we wrocławskiej wodzie wodociagowej (Raporty Wydziału Inżynierii Środowiska Politechniki Wrocławskiej, seria SPR, nr 28, Wrocław, 2018)

19. A. Grabińska-Łoniewska, G. Wardzyńska, E. Pajor, D. Korsak, K. Boryń, Polish J. Microbiol. 56, 129-138 (2007)

20. Regulation of the Minister of Health from December 7, 2017 on the quality of water intended for human consumption (in Polish), Dz. U. 2017, poz. 2294

21. M. Wolf, T. M. Traczewska, K. Leluk, T. Grzebyk, Desalin. Water Treat. 131, 169-179 (2018)

22. A. Farkas, C. Crăciunaş, C. Chiriac, E. Szekeres, C. Coman, A. Butiuc-Keul, Microb. Ecol. 72, 773-782 (2016)

23. H. Volkmann, T. Schwartz, P. Bischoff, S. Kirchen, U. Obst, J. Microbiol. Methods 56, 277-286 (2004)

24. KORLD (http://korld.edu.pl/) 